\section{Responses of Eastern Red Cedar to Control Procedures ${ }^{1}$}

\section{NORMIE BUEHRING, P. W. SANTELMANN, AND HARRY M. ELWELL}

Research Assistant and Professor, Oklahoma Agricultural Experiment Station; and Research Agronomist, Crops Research Division, Agricultural Research Service, U. S. Department of Agriculture, Stillwater, Oklahoma.

\section{Highlight}

Various chemical, mechanical, and burning procedures were evaluated for control of eastern red cedar (Juniperus virginiana L.). Injection treatments of picloram caused $\mathbf{7 0}$ to $100 \%$ desiccation and plant kill at several dates of application but 2,4,5-T did not. High rates of granular picloram applied in either August or March caused greater desiccation than did lower rates. Picloram alone or in combination with 2,4,5-T or 2,4-D as wetting foliar-stem treatments caused good kill, as did high rates of other herbicides. Low volume foliar treatments of picloram plus 2,4,5-T killed much but not all top growth. Sprouts occurred on $22 \%$ of the mowed small (0.5 to 1.25 inch basal diameter) trees. Trees less than 3 feet tall were more easily killed by burning than larger trees. Wheat (Triticum aestivum L.) and little bluestem (Andropogon scoparius Michx.) seed germination was not affected by water-extracts of eastern red cedar, but switchgrass (Panicum virgatum L.) germination was. The reverse was true of coleoptile growth.

Eastern red cedar (Juniperus virginiana L.), a tree species native to Oklahoma, is found in every state east of the 100th meridian. The wide distribution of this species indicates its ability to grow under varying climatic conditions. Eastern red cedar is a slow growing evergreen and is not an aggressive competitor with hardwoods on sites having deep soils. However, it grows on shallow soil sites where hardwood growth is sparse.

According to a survey made in 1968 eastern red cedar has invaded about 350,000 acres of Oklahoma prairie rangeland. Fire has been studied as a method for controlling this species. Martin and Crosby (1955) and Dalrymple (1969) reported that as tree size increased injury from fire decreased.

\footnotetext{
${ }^{1}$ Journal article no. 2014 of the Agricultural Experiment Station, Oklahoma State University, Stillwater. Research conducted by Department of $\Lambda$ gronomy in cooperation with the Crops Research Division, Agricultural Research Service, United States Department of Agriculture. This research part of an M.S. thesis submitted by senior author to Oklahoma State University. Received October 9, 1970; accepted for publication February 4, 1971.
}

Kirch and Esposito (1967), in control studies with herbicides, reported that 2,4-D $+2,4,5-\mathrm{T}$ plus $\mathrm{pi}-$ cloram applied at $4.0+4.0+0.75$ pounds acid equivalent per acre (lb./acre) killed $80 \%$ of this species. They found that $2,4-\mathrm{D}+2,4,5-\mathrm{T}$ plus dicamba was ineffective. For common and chemical names of herbicides discussed and used, see Table 1. Eastern red cedar was found by Kirch, Waldrum, and Brown in 1960 not to be effected by 2,4-D + 2,4,5-T applied at $3+3 \mathrm{lb}$./acre. Watson and Wiltse (1964) found that picloram at one pound active ingredient per 100 gallons (aihg) of water applied as wetting spray killed all plants. Dalrymple (1969) reported that picloram, dicamba, paraquat, picloram + paraquat, and ammonium sulfamate in foliar sprays caused at least $90 \%$ defoliation of eastern red cedar 3 months after treatment. Shipmann (1963) reported that red cedar was susceptible to granular soil applications of fenuron at 1 teaspoon/inch of stem diameter. Effective control of cedars (Juniperus spp.) with granular soil applied picloram was also reported by Wiltse (1964) and Schwartzbeck (1965).

This study was conducted to evaluate the effects of chemical, mechanical, and burning procedures for control of eastern red cedar. Studies were also conducted on the effect of water-extracts of red cedar seed and foliage on germination and coleoptile growth of grasses.

\section{Study Area and Methods}

The study area in central Oklahoma consisted of a mixture of tree species with eastern red cedar being dominant. Other species present were post oak (Quercus stellata Wang.) and blackjack oak (Quercus marilandica Muenchh.).

Experiments were conducted utilizing various herbicide application techniques as well as mechanical and burning procedures. The following is a list of the various experiments conducted and their dates of application.

I. Field Experiments

A. Herbicide application methods evaluated

1. Injection treatments made on December 20, 1967, March 25, 1968 or August 8, 1968.

2. Granular herbicides were applied on March 25 or August 28, 1968.

3. Foliar-stem sprays were applied to small (3-4 ft) or large $(7-8 \mathrm{ft})$ trees on June 7 to 10,1968 .

4. Low volume (10 gpa) foliar applications were made on June 15, 1968.

B. Other control methods evaluated

1. Mowing of various tree sizes with a chain saw or rotary mower. 
Table 1. Chemical and common names of the herbicides discussed in this paper.

\begin{tabular}{lc}
\hline Common name & Chemical name \\
\hline Picloram & 4-amino-3,5,6-trichloropicolinic acid \\
2,4-D & (2,4-dichlorophenoxy) acetic acid \\
2,4,5-1 & (2,4,5-trichlorophenoxy) acetic acid \\
Fenuron & 1,1-dimcthyl-3-phenylurea \\
Fenac & $(2,3,6$-trichlorophenyl) acetic acid \\
Dicamba & 3,6-dichloro-o-anisic acid \\
Paraquat & 1,1'-dimethyl-4,4'-bipyridinium ion \\
Endothal & 7-oxabicyclo [2.2.1] heptane-2,3- \\
& dicarboxylic acid \\
Monuron TCA & 3-(p-chlorophenyl)-1,1-dimethylurea \\
& mono (trichloroacetate) \\
Amitrole & 3-amino-s-triazole \\
NH SCN & Ammonium thiocyanate \\
Dichloroprop & 2-(2,4-dichlorophenoxy) propionic acid \\
\hline
\end{tabular}

2. Broadcast burning of areas with trees of various sizes on March 28 and April 17, 1968 at 2 different locations.

II. Laboratory experiments: The influence of water-extracts of cedar seed and foliage on germination and coleoptile growth of grasses.

In the hcrbicide application experiments each treatment was applied to ten replications with one tree per replication. Applications were made to trees 4-6 inch diameter at breast height $(\mathrm{DBH})$. Low volume foliar applications were made to trees 4-6 ft tall. Various formulations of 2,4-D, 2,4,5-T, or picloram were applied as injection treatments. One incision per inch $\mathrm{DBH}$ was made with a water filled tree injector at a 45 degree angle around the base of each tree, approximately 2 inches above the soil line. The desired amount of chemical was then inserted into each incision with an automatic syringe.

Propylene glycol butyl ether esters of 2,4-D and 2,4,5-T; the triethyl amine salt of 2,4-D and 2,4,5-T; and the potassium salt of picloram were applied either diluted or undiluted as indicated in Table 2. The amine salts were diluted with water and the ester was diluted with diesel oil, at a ratio of either 1 to 9 [0.4 $\mathrm{lb}$ active ingredient (ai)] or 1 to 4 ( $0.8 \mathrm{lb} \mathrm{ai} /$ gal carrier) of herbicide to carrier.

Granular herbicide applications were made as teaspoons (tsp) of commercially formulated granular herbicide per inch DBH. The granules were placed on the soil by hand within a 12 inch radius around the tree trunk. Foliar-stem applications were made with an adjustable hand gun nozzle attached to a tractor-mounted piston sprayer. Each tree was wetted to the point of run-off with the spray solution. Water was used as a carrier. Low volume foliar applications were made with a portable sprayer pressurized at 40 psi. Each tree was enclosed in a polyethylene covered metal frame $4 \times 4 \times 8 \mathrm{ft}$, and then the spray solution was applied over the top of each tree. Fourteen $\mathrm{ml}$ of spray solution were applied per $4 \times 4 \mathrm{ft}$ soil area, which was equivalent to 10 gpa.

Other control methods evaluated were mowing and burning. In the mowing the trees were cut off 6 inches above the soil line. Fifty trees ranging from 0.5 to 1.25 inches in diameter were cut-off with a tractor-mounted rotary-mower. Twenty trees each of 3 sizcs $(0.25$ to $0.75,0.75$ to $1.5,1.5$ to 3.0 inch basal diameter) were cut off with a chain saw. Sixteen months after cutting all stumps with new growth were counted and are expressed (Table 5) as percent of stumps with regrowth.

Broadcast burn experiments were conducted on two sites approximately 4 miles apart. Each site was 0.5 acres in size and contained trees in three height size categories: less than

Table 2. Percentage desiccation and kill of eastern red cedar 14, 18, and 21 months after injection with undiluted and diluted herbicides. ${ }^{1}$

\begin{tabular}{|c|c|c|c|c|c|c|c|c|}
\hline \multirow[b]{2}{*}{ Herbicide $^{2}$} & \multirow{2}{*}{$\begin{array}{r}\text { Dilution'2 } \\
\text { (lb. ai/gal) }\end{array}$} & \multirow{2}{*}{$\begin{array}{c}\text { Rate } \\
\text { (ml/inch } \\
\text { DBH) }\end{array}$} & \multicolumn{2}{|c|}{$\begin{array}{l}14 \text { months after } \\
\text { August treatment }\end{array}$} & \multicolumn{2}{|c|}{$\begin{array}{l}18 \text { months after } \\
\text { March treatment }\end{array}$} & \multicolumn{2}{|c|}{$\begin{array}{l}21 \text { months after } \\
\text { December treatment }\end{array}$} \\
\hline & & & Desic. & Kill & Desic. & Kill & Desic. & Kill \\
\hline $2,4,5$ - $\mathrm{T}$ ester & 4.0 & 1 & $0 b^{1}$ & 0 & $0 \mathrm{e}$ & 0 & $0 \mathrm{e}$ & 0 \\
\hline 2,4,5-T ester & 4.0 & 3 & $0 \mathrm{~b}$ & 0 & $0 \mathrm{e}$ & 0 & $0 \mathrm{e}$ & 0 \\
\hline 2,4,5-T ester & 0.4 & 1 & $0 \mathrm{~b}$ & 0 & $0 \mathrm{e}$ & 0 & $0 \mathrm{e}$ & 0 \\
\hline $2,4,5$ - $\mathrm{T}$ ester & 0.8 & 1 & $0 \mathrm{~b}$ & 0 & $0 \mathrm{e}$ & 0 & $0 \mathrm{e}$ & 0 \\
\hline $2,4,5-\mathrm{T}$ amine & 4.0 & 1 & $12 \mathrm{~b}$ & 0 & $59 \mathrm{bc}$ & 0 & $2 \mathrm{e}$ & 0 \\
\hline 2,4,5-T amine & 4.0 & 3 & $15 \mathrm{~b}$ & 0 & $65 \mathrm{bc}$ & 0 & $20 \mathrm{~d}$ & 0 \\
\hline $2,4,5-T$ amine & 0.8 & 1 & $0 \mathrm{~b}$ & 0 & $4 \mathrm{e}$ & 0 & $1 \mathrm{e}$ & 0 \\
\hline 2,4-D ester & 4.0 & 1 & $0 \mathrm{~b}$ & 0 & $2 \mathrm{e}$ & 0 & $2 \mathrm{e}$ & 0 \\
\hline 2,4-D ester & 4.0 & 3 & $9 \mathrm{~b}$ & 0 & $35 \mathrm{~d}$ & 0 & $3 \mathrm{e}$ & 0 \\
\hline 2,4-D ester & 0.4 & 1 & $0 \mathrm{~b}$ & 0 & $0 \mathrm{e}$ & 0 & $2 \mathrm{e}$ & 0 \\
\hline 2,4-D ester & 0.8 & 1 & $0 \mathrm{~b}$ & 0 & $0 \mathrm{e}$ & 0 & $2 \mathrm{e}$ & 0 \\
\hline 2,4-D amine & 4.0 & 1 & $0 \mathrm{~b}$ & 0 & $1 \mathrm{e}$ & 0 & $24 \mathrm{~d}$ & 0 \\
\hline 2,4-D amine & 4.0 & 3 & $27 \mathrm{~b}$ & 0 & $50 \mathrm{~cd}$ & 0 & $66 c$ & 0 \\
\hline 2,4-D amine & 0.8 & 1 & $0 \mathrm{~b}$ & 0 & $0 \mathrm{e}$ & 0 & $1 \mathrm{e}$ & 0 \\
\hline Picloram K-salt & 2.0 & 0.5 & 92 a & 50 & $73 \mathrm{~b}$ & 10 & $68 \mathrm{c}$ & 30 \\
\hline Picloram K-salt & 2.0 & 1 & $100 \mathrm{a}$ & 100 & 98 a & 80 & $90 \mathrm{~b}$ & 50 \\
\hline Picloram K-salt & 2.0 & 3 & $100 \mathrm{a}$ & 100 & $100 \mathrm{a}$ & 100 & $100 \mathrm{a}$ & 100 \\
\hline Control & - & - & $0 \mathrm{~b}$ & 0 & $0 \mathrm{e}$ & 0 & $0 \mathrm{e}$ & 0 \\
\hline
\end{tabular}

${ }^{1}$ Numbers followed by the same letter in a column are not significantly different at the $5 \%$ level.

${ }^{2}$ The 2 and $4 \mathrm{lb}$ ai/gallon were applied undiluted as commercial formulations. 
$1.5 \mathrm{ft}$ (small), 1.5 to $3.0 \mathrm{ft}$ (medium), 3-6 ft tall (large). One plot was burned on March 28, 1968 when most vegetation was dormant and the other was burned on April 17, 1968 shortly after vegetation had broken winter dormancy.

The dominant grass species on the March and April burn sites were three awn (Aristida oligantha Michx.) and little bluestem (Andropogon scoparius Michx.), respectively. Foliage (weed and grass) samples were obtained from both sites just before burning and oven dried 24 hours to determine dry foliage yield as an indication of the amount of available fuel to carry the fire.

All field experiments were usually evaluated on a visual rating scale of $0-10(0=$ no dessication, ranging up to $10=$ complete desiccation) at various intervals after treatment. The average ratings were converted to percent desiccation by multiplication by a factor of 10 and arc expressed as such in the tables. The number of trees which showed complete desiccation were counted and this was expressed as a percent kill.

A laboratory experiment was conducted to determine the effect of water-extracts of seed, dried green foliage or partially decomposed foliage of eastern red cedar on germination and growth of wheat (Triticum aestivum L.), switchgrass (Panicum virgatum L.), and little bluestem (Andropogon scoparius Michx.). Green foliage and seeds were collected from cedar trees and partially decomposed foliage was collected from the ground beneath the trees. The green foliage was allowed to air dry 5 days. Fifty grams of foliage or seeds were soaked in $500 \mathrm{ml}$ distilled water 48 hours. The water extracts were removed by filtering through cheesecloth. The $\mathrm{pH}$ of the water extracts was measured with a $\mathrm{pH}$ meter in order to determine if a difference in $\mathrm{pH}$ existed among the various extracts.

Twenty $\mathrm{ml}$ of the water-extract were placed in each germination box, which contained a layer of absorbent material and 25 grass seeds. Each germination box was considered a replication with 4 replications per treatment. Distilled water was used as a control treatment. The gcrmination boxes were placed in a germinator maintained at 75-85 $\mathrm{F}$ with a 12 hour daylight period. Percent germination and coleoptile lengths of various grass species were determined 5 days after being placed in the germinator.

\section{Results and Discussion}

Undiluted amines of 2,4-D or 2,4,5-T injected in March and undiluted 2,4-D amine injected in December caused the most effective desiccation for the phenoxy herbicide treatments (Table 2). However, neither killed any trees. Diluted treatments of esters and amines of 2,4,5-T or 2,4-D caused only a slight browning of the needles or no desiccation. Injected picloram killed the trees at all dates and rates of application. However the low ratc caused greater desiccation when applied in August. Some of this difference could be attributed to variations in the rating interval after treatment. The higher rates of picloram caused more than $90 \%$ desiccation with all dates of application.

The high rates of fenac, fenuron, and picloram $(10 \%)$ were the most effective granular soil treatments on both dates of application (Table 3). The 3 and 6 tsp rates of picloram caused greater than $70 \%$ plant kill regardless of date. The high rates
Table 3. Percentage desiccation and kill of eastern red cedar 13 and 17 months after soil application of granular herbicides. $^{1}$

\begin{tabular}{|c|c|c|c|c|c|}
\hline \multirow[b]{2}{*}{ Herbicides } & \multirow{2}{*}{$\begin{array}{c}\text { Rates } \\
\text { (tsp/inch } \\
\text { DBH })^{2}\end{array}$} & \multicolumn{2}{|c|}{$\begin{array}{l}13 \text { months after } \\
\text { August treatment }\end{array}$} & \multicolumn{2}{|c|}{$\begin{array}{l}17 \text { months after } \\
\text { March treatment }\end{array}$} \\
\hline & & Desic. & Kill & Desic. & Kill \\
\hline Picloram $(2 \%)^{3}$ & 1 & $1 \mathrm{f}^{1}$ & 0 & $0 \mathrm{~g}$ & 0 \\
\hline Picloram $(2 \%)$ & 3 & $10 \mathrm{de}$ & 10 & 20 efg & 10 \\
\hline Picloram (2\%) & 6 & $40 \mathrm{cde}$ & 0 & $30 \mathrm{ef}^{\circ}$ & 10 \\
\hline Piclorain (10\%) & 1 & $75 \mathrm{abc}$ & 40 & $75 \mathrm{abc}$ & 60 \\
\hline Picloram (10\%) & 3 & 95 a & 90 & 95 a & 70 \\
\hline Picloram (10\%) & 6 & $75 \mathrm{abc}$ & 70 & $90 \mathrm{ab}$ & 80 \\
\hline Dicamba (10\%) & 1 & $1 \mathrm{f}$ & 0 & $10 \mathrm{fg}$ & 0 \\
\hline Dicamba $(10 \%)$ & 3 & $1 \mathrm{f}$ & 0 & $0 \mathrm{~g}$ & 0 \\
\hline Dicamba (10\%) & 6 & 40 cde & 20 & $7 \mathrm{fg}$ & 0 \\
\hline Fenuron $(25 \%)$ & 1 & 35 cde & 10 & $27 \mathrm{efg}$ & 0 \\
\hline Fenuron $(25 \%)$ & 2 & 45 bcde & 20 & $25 \mathrm{efg}$ & 0 \\
\hline Fenuron $(25 \%)$ & 3 & $60 \mathrm{abcd}$ & 40 & $81 \mathrm{ab}$ & 60 \\
\hline Fenac $(10 \%)$ & 3 & 30 def & 10 & 30 ef & 0 \\
\hline Fenac (10\%) & 6 & $65 \mathrm{abcd}$ & 20 & $63 \mathrm{bcd}$ & 40 \\
\hline Fenac $(10 \%)$ & 9 & $75 \mathrm{abc}$ & 50 & $85 \mathrm{ab}$ & 80 \\
\hline Monuron TCA & & & & & \\
\hline$(11 \%)$ & 3 & 50 bcde & 10 & $50 \mathrm{~cd}$ & 30 \\
\hline Monuron TCA & & & & & \\
\hline$(11 \%)$ & 6 & 50 bcde & 10 & $10 \mathrm{de}$ & 20 \\
\hline Monuron TCA & & & & & \\
\hline$(11 \%)$ & 9 & 45 bcde & 20 & 45 de & 20 \\
\hline Control & - & $0 \mathrm{f}$ & $\mathbf{0}$ & $0 \mathrm{~g}$ & 0 \\
\hline
\end{tabular}

\footnotetext{
${ }^{1}$ Numbers in one column followed by the same letter are not significantly different at the $5 \%$ level.

${ }^{2}$ tsp $=$ teaspoon.

${ }^{3}$ Figures in parentheses are the $\%$ ai in the commercial formulation used.
}

of fenuron and fenac caused greater plant kill with the March treatment. Picloram (2\%), dicamba, and monuron-TCA all caused less than $50 \%$ desiccation with both dates of application.

Small and large trees responded similarly to herbicides used in wetting sprays (Table 4). Picloram, alone or in combination with 2,4-D or 2,4,5-T killed all plants, as did paraquat and ammonium sulfamate. However, these treatments had a sterilizing effect on the soil beneath the trees. Fifteen months after treatment no grass or other vegetation was found growing beneath or adjacent to the trees. Treatments of 2,4-D, 2,4,5-T, or amitrole plus $\mathrm{NH}_{4} \mathrm{SCN}$ caused some desiccation but did not kill any trees. However, 2,4,5-T in combination with low rates of paraquat killed most plants. High rates of 2,4,-D + dichlorprop and dicamba were also effective.

Low volume foliage sprays of paraquat and picloram $+2,4,5-\mathrm{T}$ killed the tops of most treated plants (Table 5). Picloram $+2,4,5-\mathrm{T}$ was the most phytotoxic treatment. Increasing effectiveness rcsulted from increasing rates. The trees which were not completely desiccated 15 months after treatment were regrowing from the apex of the branches. None of the treatments had an adverse 
Table 4. Percentage desiccation and kill of different sizes of eastern red cedar trees 15 months after a drenching foliar-stem herbicide application. ${ }^{1}$

\begin{tabular}{|c|c|c|c|c|c|}
\hline \multirow[b]{2}{*}{ Herbicide $^{2}$} & \multirow{2}{*}{$\begin{array}{c}\text { Rate } \\
\text { (aihg) }^{3}\end{array}$} & \multicolumn{2}{|c|}{ Desiccation } & \multicolumn{2}{|c|}{ Kill } \\
\hline & & Small & Large $\mathrm{S}$ & Small L & Large \\
\hline $2,4,5-\mathrm{T}$ & 4 & $27 \mathrm{e}$ & 19 de & 0 & 0 \\
\hline $2,4,5-\mathrm{T}$ & 6 & $54 \mathrm{~d}$ & $29 \mathrm{~d}$ & 0 & 0 \\
\hline $2,4,5-\mathrm{T}+\mathrm{NH}_{4} \mathrm{SCN}$ & $3.0+0.75$ & $25 \mathrm{e}$ & $15 \mathrm{e}$ & 0 & 0 \\
\hline $2,4,5-\mathrm{T}+$ paraquat & $2.0+0.5$ & $99 \mathrm{a}$ & - & 90 & - \\
\hline $2,4,5-\mathrm{T}+$ paraquat & $4.0+0.25$ & $99 \mathrm{a}$ & $98 \mathrm{a}$ & 90 & 80 \\
\hline $2,4,5-\mathrm{T}+$ paraquat & $4.0+0.5$ & $100 \mathrm{a}$ & $100 \mathrm{a}$ & 100 & 100 \\
\hline Paraquat + Surf. & $1.0+0.5 \%$ & $100 \mathrm{a}$ & - & 100 & - \\
\hline Paraquat + Surf. & $4.0+0.5 \%$ & $100 \mathrm{a}$ & $100 \mathrm{a}$ & 100 & 100 \\
\hline Dicamba & 1.5 & $78 \mathrm{~b}$ & - & 40 & - \\
\hline Dicamba & 3.0 & $100 \mathrm{a}$ & $98 \mathrm{a}$ & 100 & 80 \\
\hline Dicamba & 6.0 & $100 \mathrm{a}$ & $100 \mathrm{a}$ & 100 & 100 \\
\hline Dicamba $+2,4,5-\mathrm{T}$ & $1.5+2.0$ & $69 \mathrm{bc}$ & $=58 \mathrm{c}$ & 30 & 20 \\
\hline Dicamba $+2,4,5-\mathrm{T}$ & $2.0+4.0$ & $98 \mathrm{a}$ & $90 \mathrm{ab}$ & 80 & 60 \\
\hline 2,4-D & 4.0 & $30 \mathrm{e}$ & $20 \mathrm{de}$ & 0 & 0 \\
\hline 2,4-D & 6.0 & $70 \mathrm{~b}$ & $49 \mathrm{c}$ & 0 & 0 \\
\hline 2,4-D + dichloroprop & $2.0+2.0$ & $56 \mathrm{~cd}$ & - & 10 & - \\
\hline 2,4-D + dichloroprop & $4.0+4.0$ & $93 \mathrm{a}$ & $80 \mathrm{~b}$ & 80 & 50 \\
\hline 2,4-D + dichloroprop & $8.0+8.0$ & $95 \mathrm{a}$ & 99 a & 80 & 90 \\
\hline Amitrole $+\mathrm{NH}_{4} \mathrm{SCN}$ & $3.0+3.0$ & $29 \mathrm{e}$ & $24 \mathrm{de}$ & 0 & 0 \\
\hline Ammonium sulfamate & 50.0 & $100 \mathrm{a}$ & - & 100 & - \\
\hline Ammonium sulfamate & 75.0 & $100 \mathrm{a}$ & $100 \mathrm{a}$ & 100 & 100 \\
\hline Picloram & 0.75 & $100 \mathrm{a}$ & - & 100 & - \\
\hline Picloram & 1.5 & $100 \mathrm{a}$ & $100 \mathrm{a}$ & 100 & 100 \\
\hline Picloram + 2,4-D & $1.0+2.0$ & $100 \mathrm{a}$ & - & 100 & - \\
\hline Picloram + 2,4-D & $3.0+6.0$ & $100 \mathrm{a}$ & $100 \mathrm{a}$ & 100 & 100 \\
\hline Picloram + 2,4,5-T & $2.0+2.0$ & $100 \mathrm{a}$ & - & 100 & - \\
\hline Picloram + 2,4,5-T & $4.0+4.0$ & $100 \mathrm{a}$ & $100 \mathrm{a}$ & 100 & 100 \\
\hline Control & - & $0 \mathrm{f}$ & $0 \mathrm{f}$ & 0 & 0 \\
\hline
\end{tabular}

${ }^{1}$ Numbers in a column followed by the same letter are not significantly different at the $5 \%$ level.

${ }^{2} \mathrm{NH}_{4} \mathrm{SCN}$ is ammonium thiocyanate. Surf. is alkyl phenoxy polyoxy ethylene surfactant used as a wetting agent at $0.5 \%$ by volume.

${ }^{3}$ Rate is expressed as pounds of aing of carrier.

effect on the grass in the treated zone. Although paraquat desiccated the grass at the time of treatment there was no visible injury fifteen months after treatment.

Eastern red cedar is considered a non-root sprouting species. However, regrowth occurred on some of the stumps of small trees which had been mowed 6 inches above the soil line (Table 6). Regrowth occurred on $20 \%$ of stumps of trees with a basal diameter 0.25 to 0.75 inches. Twenty-two percent of trees ( 0.5 to 1.25 inch basal diameter) mowed with a tractor-mounted rotary-mower sprouted from the stumps. Most of these sprouts occurred on stumps which were less than one inch in basal diameter. The regrowth is attributed to the sixinch mowing height which did not cut below the bud zone of the small trees. No regrowth occurred from trees larger than 0.75 inch basal diameter which were cut off with a chain saw.

Forage yield samples collected before burning
Table 5. Percentage desiccation and kill of eastern red cedar 2 and 15 months after low volume (10 gpa) herbicide application. ${ }^{1}$

\begin{tabular}{lllcr}
\hline \hline \multirow{2}{*}{ Herbicide } & \multicolumn{1}{c}{$\begin{array}{c}\text { Rate } \\
\text { (lb./acre) }\end{array}$} & \multicolumn{2}{c}{ Desiccation } & \\
\cline { 3 - 4 } & $2 \mathrm{mo}$. & $15 \mathrm{mon}$. & Kill \\
\hline Amitrole & 0.75 & $1 \mathrm{f}$ & $0 \mathrm{~g}$ & 0 \\
Amitrole & 1.5 & $0 \mathrm{f}$ & $2 \mathrm{~g}$ & 0 \\
Ammonium sulfamate & 6.0 & $14 \mathrm{de}$ & $13 \mathrm{fg}$ & 0 \\
$\mathrm{NH}_{4} \mathrm{SCN}$ & 0.75 & $0 \mathrm{f}$ & $0 \mathrm{~g}$ & 0 \\
$\mathrm{NH}_{4} \mathrm{SCN}$ & 1.5 & $0 \mathrm{f}$ & $2 \mathrm{~g}$ & 0 \\
$2,4,5-\mathrm{T}+\mathrm{NH}_{4} \mathrm{SCN}$ & $2.0+0.75$ & $3 \mathrm{ef}$ & $0 \mathrm{~g}$ & 0 \\
$2,4,5-\mathrm{T}+\mathrm{NH}_{4} \mathrm{SCN}$ & $2.0+1.5$ & $2 \mathrm{ef}$ & $0 \mathrm{~g}$ & 0 \\
$2,4,5-\mathrm{T}+$ picloram & $2.0+0.5$ & $67 \mathrm{~b}$ & $39 \mathrm{~d}$ & 10 \\
$2,4,5-\mathrm{T}+$ picloram & $2.0+1.0$ & $74 \mathrm{~b}$ & $64 \mathrm{c}$ & 30 \\
$2,4,5-\mathrm{T}+$ picloram & $2.0+2.0$ & $82 \mathrm{a}$ & $91 \mathrm{a}$ & 70 \\
Endothal & 2.5 & $17 \mathrm{~cd}$ & $15 \mathrm{efg}$ & 0 \\
Endothal & 5.0 & $28 \mathrm{c}$ & $15 \mathrm{efg}$ & 0 \\
2,4,5-I + dicamba & $2.0+1.5$ & $17 \mathrm{~cd}$ & $21 \mathrm{ef}$ & 0 \\
$2,4,5-\mathrm{T}+$ dicamba & $4.0+2.0$ & $22 \mathrm{~cd}$ & $28 \mathrm{de}$ & 0 \\
Paraquat & 0.75 & $74 \mathrm{~b}$ & $69 \mathrm{bc}$ & 30 \\
Paraquat & 1.5 & $64 \mathrm{~b}$ & $79 \mathrm{ab}$ & 40 \\
Control & & $0 \mathrm{f}$ & $0 \mathrm{~g}$ & 0 \\
\hline
\end{tabular}

${ }^{1}$ Numbers in a column followed by the same letter are not sig. nificantly different at the $5 \%$ level.

showed relatively minor differences in available fuel between the burning sites. Dry forage yield from the March 28 and April 17 burning sites were 2,000 and 2,800 lb./acre, respectively. Smaller trees at both sites were more readily killed by fire than the larger trecs (Fig. 1). Trees less than 3 feet high were equally effected by burning on the two dates but larger trees were more adversely affected by burning in April. The difference in desiccation was attributed to more grass being beneath the trees in the April burning site than in the March burning site. These results agree with those of Dalrymple (1969) and Martin and Crosby (1955) who found that the effect of fire on cedar kill decreased with increasing tree height.

The effect of the water-extracts on seed germination and seedling coleoptile growth varied with the individual species (Table 7). Wheat and little bluestem germination were not significantly affected. Increased germination of switchgrass resulted from water-extracts of fresh seed and partially decom-

Table 6. Percentage of eastern red cedar stumps with regrowth 16 months after cutting.

\begin{tabular}{lcc}
\hline \hline \multicolumn{1}{c}{ Method of cutting } & $\begin{array}{c}\text { Basal diameter } \\
\text { (inches) }\end{array}$ & $\begin{array}{c}\text { Percent of stumps } \\
\text { with regrowth }\end{array}$ \\
\hline Tractor rotary mower & 0.5 to 1.25 & 22 \\
Chain saw & 0.25 to 0.75 & 20 \\
Chain saw & 0.75 to 1.5 & 0 \\
Chain saw & 1.5 to 3.0 & 0 \\
\hline
\end{tabular}

${ }^{1}$ Fifty trees in groups of 10 were cut off with a tractor rotary mower and 20 trees each with a chain saw. 


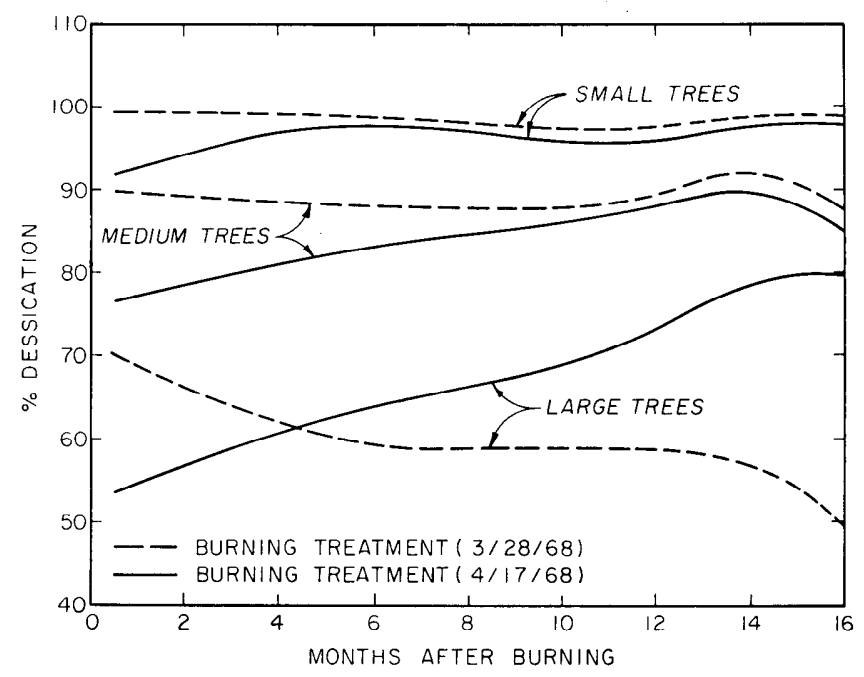

FIG. 1. Effect of date of burning and tree size on the desiccation of three different sizes of eastern red cedars.

posed foliage. Water extracts of seed and dried green foliage decreased coleoptile growth of wheat. Growth of the little bluestem coleoptile was significantly inhibited only by water extracts of dried green foliage. Switchgrass coleoptile growth was not affected.

The $\mathrm{pH}$ of the water-extracts of fresh seed, dried green foliage, and partially decomposed foliage were $4.1,4.3,5.3$, respectively.

In these experiments picloram was found to be the most effective herbicide used in wetting sprays, low volume sprays, as granules applied to the soil or in injector treatments for eastern red cedar control. Since picloram has a pcrsistent soil residuc it would probably be safest if used as injector treatments. In order to use cutting as an effective method of control for eastern red cedar the trees must be cut at about the soil surface to prevent regrowth from remaining stumps. When fire is used for eastern red cedar control grazing would need to be restricted to permit sufficient grass and
Table 7. Influence of water-extracts from seed and foliage of eastern red cedar on germination (\%) and coleoptile growth (inches) of 3 grasses.

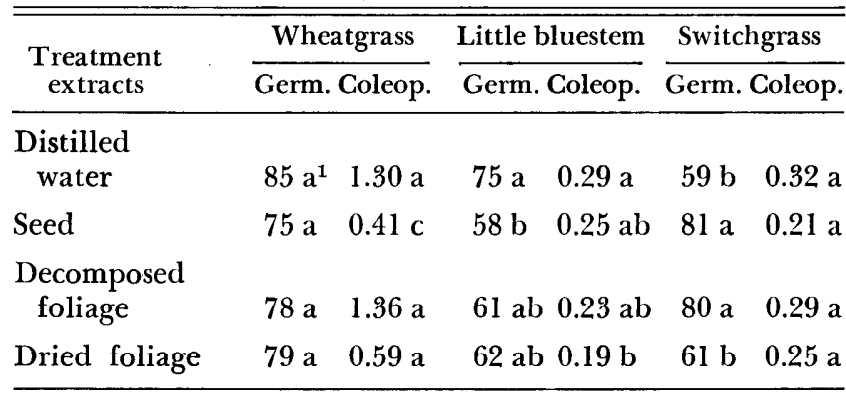

${ }^{1}$ Numbers followed by the same letter in each column are not significantly different at the $5 \%$ level.

weed cover $(1,500$ to $2,000 \mathrm{lb}$./acre) to grow to carry a fire. Then only trees under 3 feet in height may be scorched by fire sufficiently to be killed.

\section{Literature Cited}

DALky MPle, R. L. 1969. Cedar control in southern Oklahoma. S. Weed Conf. 22:272-273.

Martin, S. C., ANd J. S. Crosby. 1955. Burning on a glade range in Missouri. U.S. Forest Serv. Central Sta. Forest Exp. Sta. Tech. paper 147:13.

Kirch, J. H., J. E. Waldrum, and H. F. Brown. 1960. The invert emulsion-a promising tool for right-of-way management. Proc. N.E. Weed Conf. 11:413-418.

Kirch, J. H., AND James E. Esposito. 1967. A study of additives to the aqueous phase of aerially applied invert emulsions. Proc. S. Weed Conf. 20:251-255.

ScHWARTZBECK, R. A. 1965. 4-amino-3,5,6-trichloropicolinic acid pellets for brush control in the Northeastern United States. Proc. N.E. Weed Conf. 19:185-192.

Shipman, R. D. 1963. Pelleted silvicides-their use in controlling unwanted hardwoods in South Carolina. Forestry Res. Series No. 11, Dep. Forest. S. C., Agr. Exp. Sta., Clemson, S. C.

Watson, A. J., AND M. G. Wiltse. 1964. Tordon for brush control on utility rights-of-way in the Eastern United States. Down to Earth 19(1):11-14.

Wiltse, Mark G. 1964. Tordon herbicide as a soil sterilant for brush control. Down to Earth 19(4):3-6.

\section{ELECTION OF OFFICERS}

Ballots for the election of a president elect and two directors of SRM will be mailed to all members on or about October 1. The candidates are: Martin H. Gonzalez and Gerald W. Tomanek (for president elect), and Vinson L. Duvall, John H. Ehrenreich, F. Robert Gartner, and Donald L. Huss (for the directorships). Biographical sketches of and brief statements by the candidates appeared in the August issue of Rangeman's News.

A good index of the viability of any organization is the degree of participation by the membership in the organization's affairs. Yet, historically, the return of mail ballots by the members of any professional society is usually less than 50\%! SRM is your Society and you should express your preferences in selecting its leadership-voting requires the expenditure of only very little time and a postage stamp.

To be counted, ballots must be returned to the Executive Secretary's office postmarked no later than November 30 , 1971. 